\title{
PENDAMPINGAN CARA PERHITUNGAN DAN PELAPORAN PPh 21 KARYAWAN RSIA PERMATA HATI MATARAM
}

\author{
Bambang, Lalu Takdir Jumaidi, D. Tialurra Della Nabia \\ Fakultas Ekonomi dan Bisnis - Universitas Mataram \\ bambang@unram.ac.id
}

\begin{abstract}
ABSTRAK
Pengabdian ini bertujuan untuk mendampingi pegawai untuk menghitung dan melaporkan Pajak Penghasilan (PPh) atas gaji dan penerimaan lain yang diterima pegawai. Perhitungan jumlah pajak menggunakan excel sedangkan pelaporan menggunakan sarana e-filling yang disediakan oleh Dirjen Pajak. Meteode pengabdian terdiri dari 1) Metode ceramah, melalui metode ini peserta diberikan pengetahuan dan pemahaman melalui presentasi oleh pemateri serta motivasi agar memiliki kemauan menerapkan aplikasi. Metode ini dilakukan selama 1/2 jam, 2) Metode tutorial Peserta diberikan panduan langkah-langkah perhitungan PPh 21. Metode ini dilakukan selama 1/2 jam., 3) Sesi praktik, Peserta mempraktikkan langkah-langkah yang telah dipelajari Metode ini dilakukan selama 1 jam, 4) Metode diskusi Peserta diberikan kesempatan untuk mendiskusikan masalah yang dihadapi berkaitan dengan kesulitan dalam dalam perhitungan dan pelaporan. Metode ini dilakukan selama 1 jam.

Setelah pelatihan, pegawai telah dapat menghitung PPh 21 dan melaporkan melalui e filling.

Tantangan pelatihan adalah masih diperlukan peningkatan mengoperasikan aplikasi excel dan formula-formula tingkat intermediate dan advance, sedangkan untuk pelaporan memerlukan latihan secara berulang dan berkelanjutan.
\end{abstract}

Kata kunci: Pengabdian, PPh 21, e filling

\section{ABSTRACT}


This service aims to assist employees in calculating and reporting Income Tax (PPh) 21 on salaries and other receipts received by employees. The calculation of the amount of taxes uses excel while reporting uses the e-filling facility provided by the Director General of Taxes.

The service method consists of 1) Lecture method, through this method participants are given knowledge and understanding through presentations by presenters and motivation to have the willingness to apply the application. This method is carried out for 1/2 hour, 2) The tutorial method Participants are given a guide on the steps for calculating PPh 21. This method is carried out for $1 / 2$ hour., 3) A practice session, Participants practice the steps they have learned This method is carried out during 1 hour, 4) Discussion method Participants are given the opportunity to discuss the problems they face related to difficulties in calculation and reporting. This method is carried out for 1 hour.

After the training, employees have been able to calculate PPh 21 and report via e-filling.

The training challenge is that it is still necessary to improve the operation of excel applications and intermediate and advanced level formulas, while reporting requires repeated and continuous training.

Keyword: assist, PPh 21, e filling

\section{PENDAHULUAN}

RSIA Permata Hati merupakan rumah sakit ibu dan anak tipe $\mathrm{C}$ milik Swasta yang terletak di wilayah Mataram, Nusa Tenggara Barat. Rumah sakit ini memberikan pelayanan di bidang kesehatan khusus ibu dan anak yang didukung oleh layanan dokter spesialis dan perawat serta ditunjang dengan fasilitas medis lainnya. Dengan adanya rumah sakit masyarakat dapat memanfaatkan layanan rumah sakit untuk meningkatkan kualitas hidup. Lokasi operasional RSIA Permata Hati masih 
berdekatan dengan Universitas Mataram, yaitu di Jalan Majapahit No.30 C, Mataram.

Pajak merupakan sumber penerimaan negara yang paling utama dan yang paling besar pada APBN. Pajak merupakan sumber yang sangat penting dalam memenuhi dan menunjang kebutuhan negara. Oleh karena itu, dalam mensukseskan penerimaan pajak perlu adanya kesadaran dari berbagai pihak, terutama para wajib pajak untuk membayar pajak (ORTax, 2012). Kesadaran dan kepatuhan wajib pajak (WP) bergantung pada tingkat pengetahuan WP dalam mengurus administrasi perpajakan, yaitu mulai dari penentuan penghasilan yang menjadi obyek pajak, perhitungan dan pelaporan Pajak Penghasilan secara benar sesuai dengan ketentuan dan undang-undang perpajakan.

RSIA Permata Hati pada akhir Desember 2020 memiliki karyawan sebanyak 202 orang dan beberapa diantaranya telah memiliki penghasilan yang mengaruskan mereka untuk memenuhi kewajiban perpajakan yaitu melakukan perhitungan, pembayaran dan pelaporan pajak. Sebagian besar karwayan rumah sakit adalah tenaga medis dan tidak memiliki pengetauan mengenai aspek perpajakan atas penghasilan yang diterima di Rumah Sakit.

Selama tahun 2020 kondisi pandemi Covid-19, pemerintah mengeluarkan kebijakan mengenai insentif pajak bagi pegawai yang berdampak Pandemi Covid 19 dengan skema pajak ditanggung pemerintah (DTP). Artinya, pajak karyawan yang biasanya dipungut setiap bulan, tidak akan ditagih lagi oleh otoritas pajak. Insentif ini berlaku untuk masa pajak April hingga September 2020.

Insentif PPh Pasal 21 Ditanggung Pemerintah (DTP) diberikan untuk pegawai dari pemberi kerja dengan klasifikasi lapangan usaha seperti yang diatur dalam PMK 44/2020 tentang tentang Insentif Pajak Untuk Wajib Pajak Terdampak Pandemi Corona Virus Disease 2019 dan sebagaimana telah diubah dalam Peraturan Menteri Keuangan Nomor 
86/PMK.03/2020 tentang Insentif Pajak Untuk Wajib Pajak Terdampak Pandemi Corova Virus Disease 2019.

Pajak Penghasilan Pasal 21 (PPh 21) merupakan jenis pajak yang dikenakan terhadap penghasilan berupa gaji, upah, honorarium, tunjangan dan pembayaran lain yang diterima oleh pegawai, bukan pegawai, mantan pegawai, penerima pesangon dan lain sebagainya. Wajib Pajak atas PPh Pasal 21 adalah pegawai, penerima uang pesangon, pensiun, tunjangan hari tua, jaminan hari tua, ahli waris dan Wajib Pajak kategori bukan pegawai yang menerima atau memperoleh penghasilan sehubungan dengan pemberian jasa.

Tarif pajak yang dimuat pada PPh Pasal 21 dibebankan kepada Wajib Pajak yang telah berpenghasilan. Dalam menghitung pajak penghasilan terhutang, terlebih dahulu mengetahui besaran Penghasilan Tidak Kena Pajak (PTKP) sebagai pengurang pajak. Penghasilan Tidak Kena Pajak (PTKP) merupakan pendapatan yang tidak dikenai Pajak Penghasilan seperti yang termuat dalam PPh Pasal 21. Menurut Direktorat Jenderal Pajak, Penghasilan Tidak Kena Pajak (PTKP) dijelaskan sebagai pengeluaran untuk memenuhi kebutuhan dasar Wajib Pajak beserta keluarga, dalam satu tahun. Maka tidak termasuk dalam PPh Pasal 21.

Sebagai wajib pajak yang berstatus karyawan, pajak penghasilannya sudah dibayarkan oleh perusahaan dari pemotongan gaji setiap bulannya. Karyawan melaporkan setiap tahunnya dengan menggunakan Surat Pemberitahuan (SPT). SPT adalah surat dalam bentuk formulir yang digunakan oleh Wajib Pajak (WP) setiap kali hendak melaporkan penghitungan atau pembayaran pajak, objek pajak atau bukan objek pajak, harta dan kewajiban pajaknya sesuai aturan perpajakan yang berlaku. Karyawan harus melaporkan SPT Tahunan Pribadi karyawan setiap tahunnya sebagai bukti bahwa penghasilannya telah dipotong pemberi kerja. Pelaporan SPT Tahunan Pribadi karyawan ini diperlukan sebagai bukti bahwa perusahaan telah menyetorkan 
pemotongan PPh 21 tersebut ke kas negara. Pelaporan SPT Tahunan Pribadi karyawan ini dilakukan secara online melalui e-Filing Berdasarkan pengamatan penulis, pegawai-pegawai yang berkerja di Rumah Sakit belum memiliki pengetahuan yang memadai tentang aspek teknis perpajakan tersebut dan adanya perubahan aturan dari pemerintah terkait dengan perpajakan.

Tujuan pengadbian inin adalah mendampingi pegawai yang berkerja pada RSIA Mataram agar dapat menghitung dan melaporkan PPh 21 masing-masing.

\section{METODE KEGIATAN}

Tahapan dan materi pelaksanaan kegiatan pengabdian ini dilakukan dengan metode ceramah, tutorial, praktik dan diskusi dengan langkahlangkah berikut ini:

1. Metode ceramah

Peserta diberikan pengetahuan dan pemahaman melalui presentasi oleh pemateri serta motivasi agar memiliki kemauan mengidentifikasi, menghitung dan melaporkan pajak penghasilan yang terhutang. Metode ini dilakukan selama 1,5 jam.

2. Metode tutorial

Peserta diberikan panduan pengisian dan formulir-formulir dalam bentuk soft file untuk diisi. Metode ini dilakukan selama $1 / 2$ jam.

3. Sesi praktik

Peserta mempraktikkan langkah-langkah pengisian e spt yang telah dipelajari dan Metode ini dilakukan selama 1 jam.

4. Metode diskusi

Peserta diberikan kesempatan untuk mendiskusikan masalah yang dihadapi berkaitan dengan kesulitan dalam aspek pengisian formulir pajak. Metode ini dilakukan selama 1 jam. 
Setelah pelatihan pegawai telah dapat menghitung dan pelaporan melalui pengisian e filing sesuai dengan tata cara pengisian yang disampaikan

Tantangan pelatihan adalah masih diperlukan masih adaptasi dengan teknologi dan perubahan aturan mengenai perpajakan, khususnya Pajak atas penghasilan pegawai.

Berikut adalah contoh dan hasil perhitungan PPh 21 atas pegawai RSIA Permata Hati Mataram

Melalui penggunaan aplikasi tersebut pegawai dapat menghitung secara otomatis jumlah kewajiban perpajakan baik bulanan maupun dalam satu tahun

\begin{tabular}{|c|c|c|}
\hline \multirow{2}{*}{\multicolumn{3}{|c|}{ 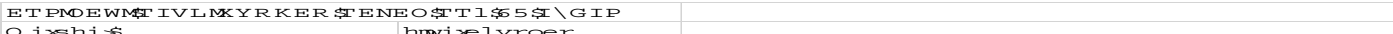 }} \\
\hline Q ixshis & & \\
\hline 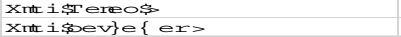 & $\begin{array}{l}\text { Kusww } \\
\text { Tike }\{\text { enkixet }\end{array}$ & \\
\hline 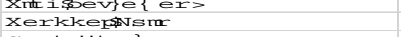 & $\begin{array}{r}\text { Tike }\{\text { entixet } \\
5 \mathbb{I N} \text { er } 164\end{array}$ & \\
\hline 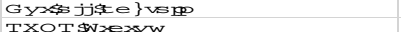 & $\begin{array}{r}5175 \\
\times 034\end{array}$ & \\
\hline TXOT\$Wrexyw & xO34 & \\
\hline NOO & 4268) & \\
\hline FTNW\$iwilever\$R Yq fiv & Jiw & \\
\hline 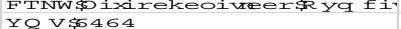 & Hor & \\
\hline $\begin{array}{l}\text { Yo V\$5464 } \\
\text { NT \$ evix } 464\end{array}$ & 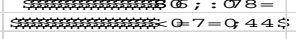 & \\
\hline \multicolumn{3}{|l|}{ Oixiverker } \\
\hline Fewrystwerev\} & 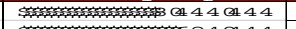 & \\
\hline $\mathrm{E}_{\text {ps }}\{$ ergise lefpi & 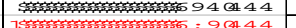 & \\
\hline $\begin{array}{l}\text { Hihygnes relefpi } \\
x \in \mid \text { seps }\{\text { ergi }\end{array}$ & 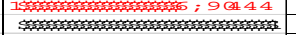 & \\
\hline FTNW\$iwilexer & $\omega_{m}$ & 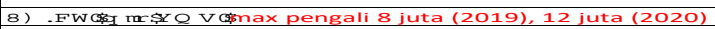 \\
\hline NOQ & 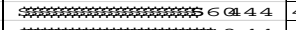 & 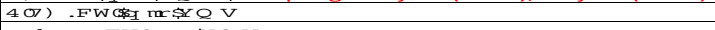 \\
\hline NOO & 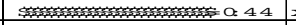 & 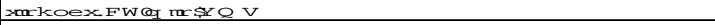 \\
\hline 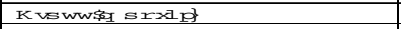 & 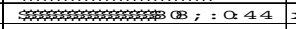 & 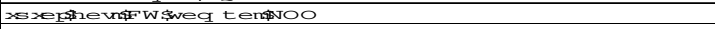 \\
\hline Kuswwstiend & $70 ; 5=644]_{1}$ & 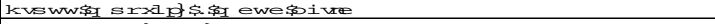 \\
\hline tswranestegswax & 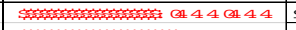 & 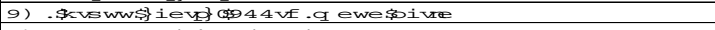 \\
\hline 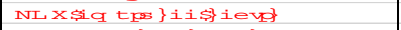 & 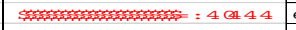 & 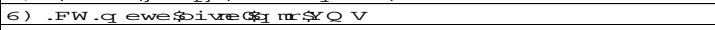 \\
\hline 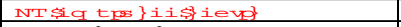 & 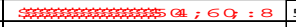 & 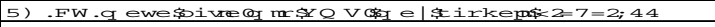 \\
\hline Rixess\}ieut & $90:=837=$ & K] IIIG INL X INT \\
\hline TXOT & 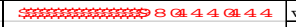 & wiwyentiotsonsexy \\
\hline тот & 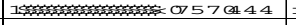 & 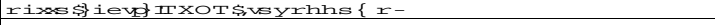 \\
\hline TTIStiend & 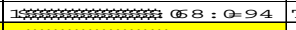 & TOT reunjovskviwng \\
\hline 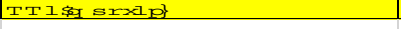 & 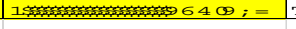 & 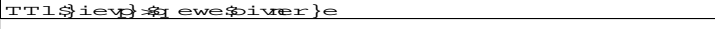 \\
\hline Fsryw3xuV & 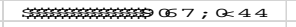 & \\
\hline \multicolumn{3}{|l|}{ Oixiverker } \\
\hline 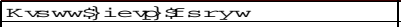 & 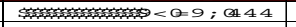 & kvswwstieupl/fsryw \\
\hline 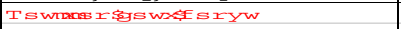 & 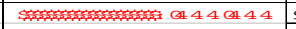 & 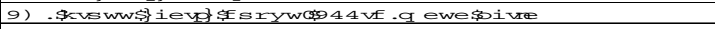 \\
\hline 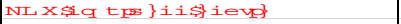 & 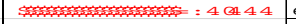 & 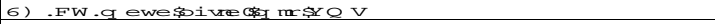 \\
\hline 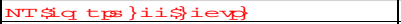 & $64 ; 69=8$ & 5) .FW-q ewe \\
\hline R ixoss\}ievdissryw & 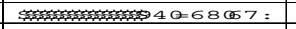 & 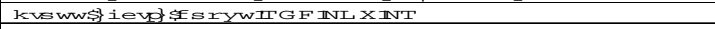 \\
\hline тXOT & 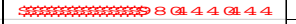 & wrexpwotrxot \\
\hline тот & 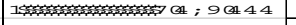 & 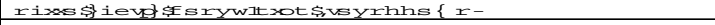 \\
\hline TT1Sieuplastryw & 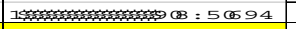 & TOT sevnjistskviwny \\
\hline TTル1\$55年SIYw & $<9 ; 44$ & 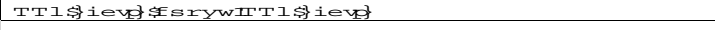 \\
\hline \multicolumn{3}{|l|}{ TTI\$65\$SXEP } \\
\hline & & \\
\hline \multirow{2}{*}{\multicolumn{3}{|c|}{\begin{tabular}{|l|l} 
Oixiverkex & $\mathrm{R} s q$ meks \\
\end{tabular}}} \\
\hline & & \\
\hline Fewrystoverev\} & $8 \% 44 \Subset 44$ & \\
\hline XLV3F SIYW & $967 ; 044$ & \\
\hline Epsos $\{$ ergi,,$e \mid e f p i-$ & $694 \% 44$ & \\
\hline Ensos $\{$ ergi,rsxhelefpi- & $; 949444$ & \\
\hline Hihygrns, $x$ elefpi- &, $6 ; 9444-$ & \\
\hline \multicolumn{3}{|l|}{ hihygrnas, Isxselefpi- } \\
\hline TT155 & $6=9 \cos 65-$ & \\
\hline 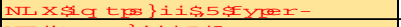 &,$<4844$ & 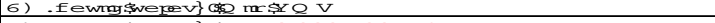 \\
\hline 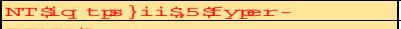 &,$\angle=O P=;$ & 5). Fewrgstwerev\} (\$3nax 8.939.700, min UMR \\
\hline FTNWक & $.564 \mathrm{CH}_{44}$ & 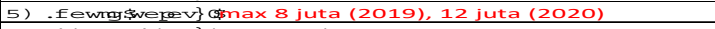 \\
\hline Xeoissisq ispe\} & $=\cos 4<\cos <6$ & 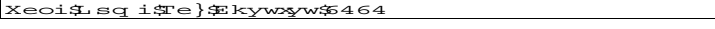 \\
\hline
\end{tabular}


Setelah melakukan pehitungan PPh 21, wajip pajak akan melaporkan SPT

Tahunan melalui e -filing SPT. Setelah melalui beberapa tahap pengisian formulir yang ada dalam aplikasi, wajib pajak akan menerima bukti penerimaan elektronik penyampaian SPT.

Berikut adalah hasil dari proses pelaporan e -filing SPT Tahunan Orang [e-Filing] Bukti Penerimaan Elektronik Eksternal Kotak Masuk $x$

efiling@pajak.go.id

kepada saya -

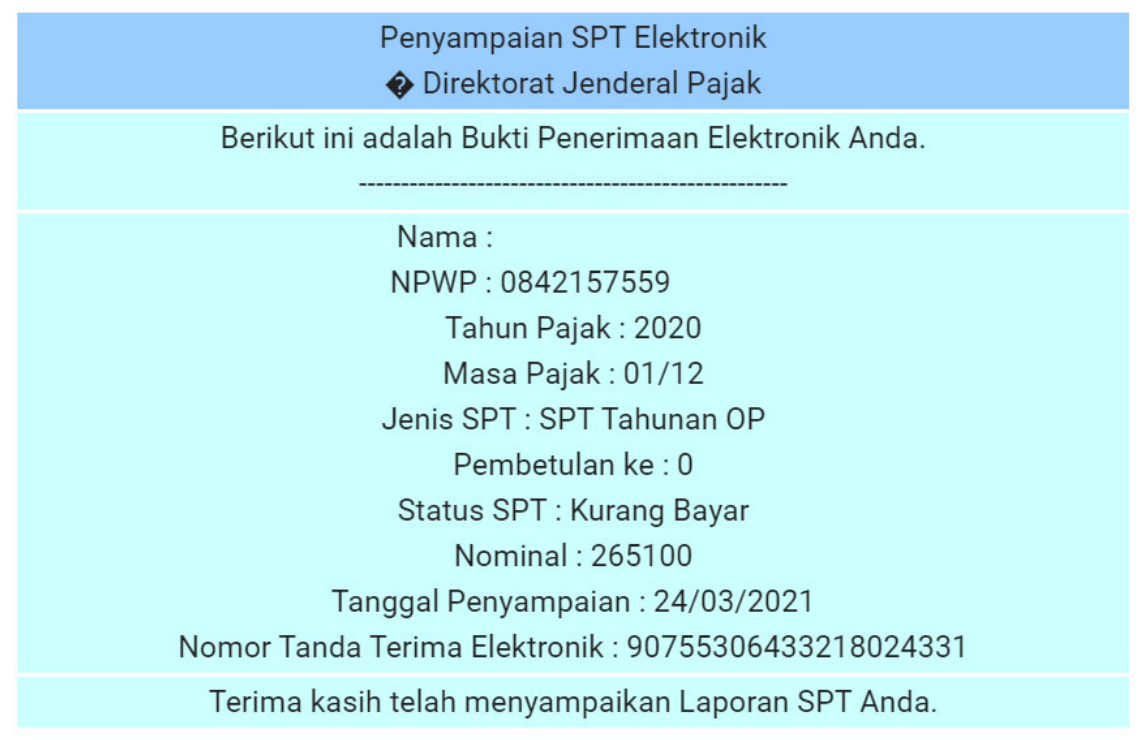

\section{KESIMPULAN DAN SARAN}

Berdasarkan hasil dan pembahasan pengabdian maka dapat disimpulkan sebagai berikut:

1. Kegiatan pengabdian masyarakat dapat berjalan lancar, pegawai Rumah Sakit, khususnya bagian administrasi dan keuangan dapat memperoleh pemahaman baru mengenai cara meningkatkan proses pelaporan surat pemberitahuan pajak

2. Pelaporan melalui e-filing lebih mudah, cepat dan aman sehingga sangat efektif dan efisien bagi setiap pegawai dalam melaporkan kewajiban perpajakan. 
3. Secara umum pegawai bagian keuangan telah mengetahui dan memahami proses kerja e filing dalam kewajiban perpajakan.

Sebagai upaya penyempurnaan berkelanjutan atas hasil pengabdian, maka disarankan sebagai berikut:

1. Pegawai yang telah memahami memahami proses e filling agar dapat meningkatkan keterampilah menjalankan aplikasi

2. Pegawai yang telah memahami memahami proses e filling agar melaporkan kewajiban perpajakan sesuai dengan waktu yang ditetapkan oleh otoritas pajak.

Kesimpulan harus mengindikasi secara jelas dan to the poin tentang jawaban dari tujuan pelaksanaan kegiatan. Kesimpulan dapat berupa paragraf, atau berbentuk point-point dengan menggunakan numbering apabila tujuan pelaksanaan kegiatan memang terdiri dari beberapa poin juga.

Saran dapat disampaikan sebagai masukan terhadap pelaksanaan kegiatan pengabdian berikutnya, agar terlaksana dengan lebih baik.

\section{DAFTAR PUSTAKA}

Klik Pajak, 2020, PPh-21-FINAL-KLIKPAJAK-ver-BARU.pdf

ORTax, 2012

Peraturan Menteri Keuangan Nomor 44/PMK.03/2020 tentang tentang Insentif Pajak Untuk Wajib Pajak Terdampak Pandemi Corona Virus Disease 2019

Peraturan Menteri Keuangan Nomor 86/PMK.03/2020 tentang Insentif Pajak Untuk Wajib Pajak Terdampak Pandemi Corova Virus Disease 2019. SPT Masa PPh Pasal 21/26 | Direktorat Jenderal Paja 